\title{
Penicillium janthinellum NCIM1366 shows improved biomass hydrolysis and a larger number of CAZymes with higher induction levels over Trichoderma reesei RUT-C30
}

AthiraRaj Sreeja-Raju ${ }^{1,2}$, Meera Christopher ${ }^{1,2}$, Prajeesh Kooloth-Valappil ${ }^{1,2}$, Rajasree Kuni-Parambil ${ }^{3}$, Digambar Vittal Gokhale ${ }^{4}$, Meena Sankar ${ }^{1,2}$, Amith Abraham $^{5}$, Ashok Pandey ${ }^{6}$ and Rajeev K. Sukumaran ${ }^{1,2^{*}}$ (1)

\begin{abstract}
Background: Major cost of bioethanol is attributed to enzymes employed in biomass hydrolysis. Biomass hydrolyzing enzymes are predominantly produced from the hyper-cellulolytic mutant filamentous fungus Trichoderma reesei RUT-C30. Several decades of research have failed to provide an industrial grade organism other than T. reesei, capable of producing higher titers of an effective synergistic biomass hydrolyzing enzyme cocktail. Penicillium janthinellum NCIM1366 was reported as a cellulase hyper producer and a potential alternative to T. reesei, but a comparison of their hydrolytic performance was seldom attempted.

Results: Hydrolysis of acid or alkali-pretreated rice straw using cellulase enzyme preparations from P.janthinellum and T. reesei indicated 37 and $43 \%$ higher glucose release, respectively, with P. janthinellum enzymes. A comparison of these fungi with respect to their secreted enzymes indicated that the crude enzyme preparation from P. janthinellum showed 28\% higher overall cellulase activity. It also had an exceptional tenfold higher beta-glucosidase activity compared to that of T. reesei, leading to a lower cellobiose accumulation and thus alleviating the feedback inhibition. P. janthinellum secreted more number of proteins to the extracellular medium whose total concentration was 1.8-fold higher than T. reesei. Secretome analyses of the two fungi revealed higher number of CAZymes and a higher relative abundance of cellulases upon cellulose induction in the fungus.

Conclusions: The results revealed the ability of P. janthinellum for efficient biomass degradation through hyper cellulase production, and it outperformed the established industrial cellulase producer T. reesei in the hydrolysis experiments. A higher level of induction, larger number of secreted CAZymes and a high relative proportion of BGL to cellulases indicate the possible reasons for its performance advantage in biomass hydrolysis.
\end{abstract}

Keywords: Penicillium janthinellum, Trichoderma reesei, Cellulase, CAZymes, Secretome, Bioethanol

*Correspondence: rajeevs@niist.res.in

${ }^{1}$ Biofuels and Biorefineries Section, Microbial Processes and Technology Division, CSIR-National Institute for Interdisciplinary

Science and Technology, Industrial Estate, Pappanamcode, Thiruvananthapuram 695019, India

Full list of author information is available at the end of the article

\section{Background}

Lignocellulosic biomass is mainly composed of three polymers-cellulose, hemicellulose, and lignin. Among them, cellulose is the most abundant component which consists of $35-50 \%$ of plant dry weight followed by hemicellulose $(20-35 \%)$ and then lignin (5-30\%) [1]. Degradation of lignocelluloses is generally carried out by

c) The Author(s) 2020. This article is licensed under a Creative Commons Attribution 4.0 International License, which permits use, sharing, adaptation, distribution and reproduction in any medium or format, as long as you give appropriate credit to the original author(s) and the source, provide a link to the Creative Commons licence, and indicate if changes were made. The images or other third party material in this article are included in the article's Creative Commons licence, unless indicated otherwise in a credit line to the material. If material is not included in the article's Creative Commons licence and your intended use is not permitted by statutory regulation or exceeds the permitted use, you will need to obtain permission directly from the copyright holder. To view a copy of this licence, visit http://creativeco mmons.org/licenses/by/4.0/. The Creative Commons Public Domain Dedication waiver (http://creativecommons.org/publicdomain/ zero/1.0/) applies to the data made available in this article, unless otherwise stated in a credit line to the data. 
a set of enzymes including ligninases, hemicellulases, cellulases and other accessory enzymes. Their relative proportions and quantities can determine the efficiency of hydrolysis [2]. The major cost involved in bioethanol production from lignocellulosic biomass is contributed by the hydrolysis step, owing to the cost of production of these enzymes [3]. Thus, reducing the cost of enzymes is critical for making the process economical. The major sources of lignocellulose-degrading enzymes are filamentous fungi, mainly the genera Trichoderma, Aspergillus and Penicillium [4]. With cellulose being the major component, cellulases play an important role in the degradation process. Cellulases are mainly divided into three major groups based on their mode of action on cellulose: (1) endoglucanases, which randomly cleave internal $\beta-1$, 4 linkages in cellulose chain generating free ends; (2) cellobiohydrolases, which act in a processive manner on either reducing or non-reducing ends of the cellulose chain, releasing cellobiose as the major product and (3) beta-glucosidases that hydrolyze cellobiose into glucose [5].

Among the filamentous fungi, Trichoderma reesei is the most studied cellulase producer and considered as the model organism for cellulase research. It was originally isolated from the Solomon Islands during the Second World War, and the isolate was named T. reesei QM6a as part of the culture collection at the US Army Quarter Master Research and Development Center at Natick, Massachusetts. Attempts to improve the cellulase production from $T$. reesei QM6a by several generations of mutagenesis resulted in an enzyme hyper-secreting mutant named as T. reesei RUT-C30 [6]. Currently, T. reesei RUT-C30 is the predominantly used industrial cellulase producer, because of its ability to produce a high titer of cellulases and a gene regulation mechanism that is highly adapted for cellulose utilization [7]. Nevertheless, the cost of cellulases is still a major concern, with only a handful of companies commercially manufacturing biomass hydrolysis enzymes, and transportation and storage of the enzyme itself adding significantly to the cost [8]. Availability of an alternate cellulase source, better than $T$. reesei in terms of higher yields, an effective ratio of different glucanases to effect improved biomass hydrolysis performance, and/or better production economics as determined by higher specific activities, shorter fermentation times, etc., would be highly advantageous to the $2 \mathrm{G}$-ethanol industry, especially in countries where commercial production of efficient biomass hydrolyzing cellulases are not available.

Penicillium janthinellum NCIM 1171 is a filamentous soil fungus known for its efficient cellulase production and hydrolysis efficiency $[9,10]$. Classical mutagenesis studies conducted at CSIR-NCL, Pune had yielded three mutants of $P$. janthinellum NCIM 1171 with enhanced cellulase production and they were named as EMS-UV-8 (NCIM1366), EU-21 and EU2D-21 [11-13]. The mutant EMS-UV-8, named as isolate NCIM 1366 was reported to have higher beta-glucosidase (BGL) activity compared to other mutants [11]. While it's enzyme was not the best in terms of hydrolyzing pure cellulose [11], it was efficient in the hydrolysis of pretreated rice straw (unpublished results).The strain was also successfully used for bioethanol production from pretreated wheat straw [14]. Since the mutant strain produced cellulases efficient in hydrolysis of natural biomass substrates, $P$. janthinellum NCIM1366 was chosen as the model strain to be compared with $T$. reesei RUT-C30, the best known industrial producer of cellulase. Secretome analyses performed using liquid chromatography tandem mass spectrometry (LC-MS/MS) revealed higher number of CAZymes in $P$. janthinellum compared to $T$. reesei, and a higher relative abundance of cellulases upon induction using cellulose, which may explain the higher activity and better biomass hydrolytic performance of enzyme preparation from the fungus.

\section{Results \\ $P$. janthinellum secretes higher amount of proteins compared to T. reesei}

Cellulose is a large polymer and utilization of it requires secretion of enzyme by microorganisms to process it outside the cell, so that the simple sugars derived from its breakdown can be taken inside. The total secreted protein concentration in presence of cellulose is indicative of the efficiency of the fungus in utilizing the polymer, as efficient cellulose digestion typically requires a milieu of different enzyme activities, in addition to cellulases. $T$. reesei showed a maximum protein secretion of $0.28 \mathrm{mg} /$ $\mathrm{ml}$ on the 6th day of growth, whereas $P$. janthinellum secreted the maximum protein on 10th day of growth which was $\sim 1.8$ times higher than T. reesei (Fig. 1a). At all the time points tested, extracellular protein concentration was higher in P. janthinellum. SDS-PAGE of the extracellular fractions from both fungi under uninduced (glucose grown) and induced (cellulose grown) conditions indicated significant elevation in secreted proteins upon cellulose induction (Fig. 1b). It was also observed that visibly, a greater number of extracellular proteins were secreted by $P$. janthinellum.

\section{P. janthinellum shows lesser cellobiose accumulation in the hydrolysis medium which is indicative of its better beta-glucosidase activity}

Cellobiose, the intermediate product of enzymatic cellulose hydrolysis, is produced through action of exoglucanases and is the substrate for cellobiase/ 

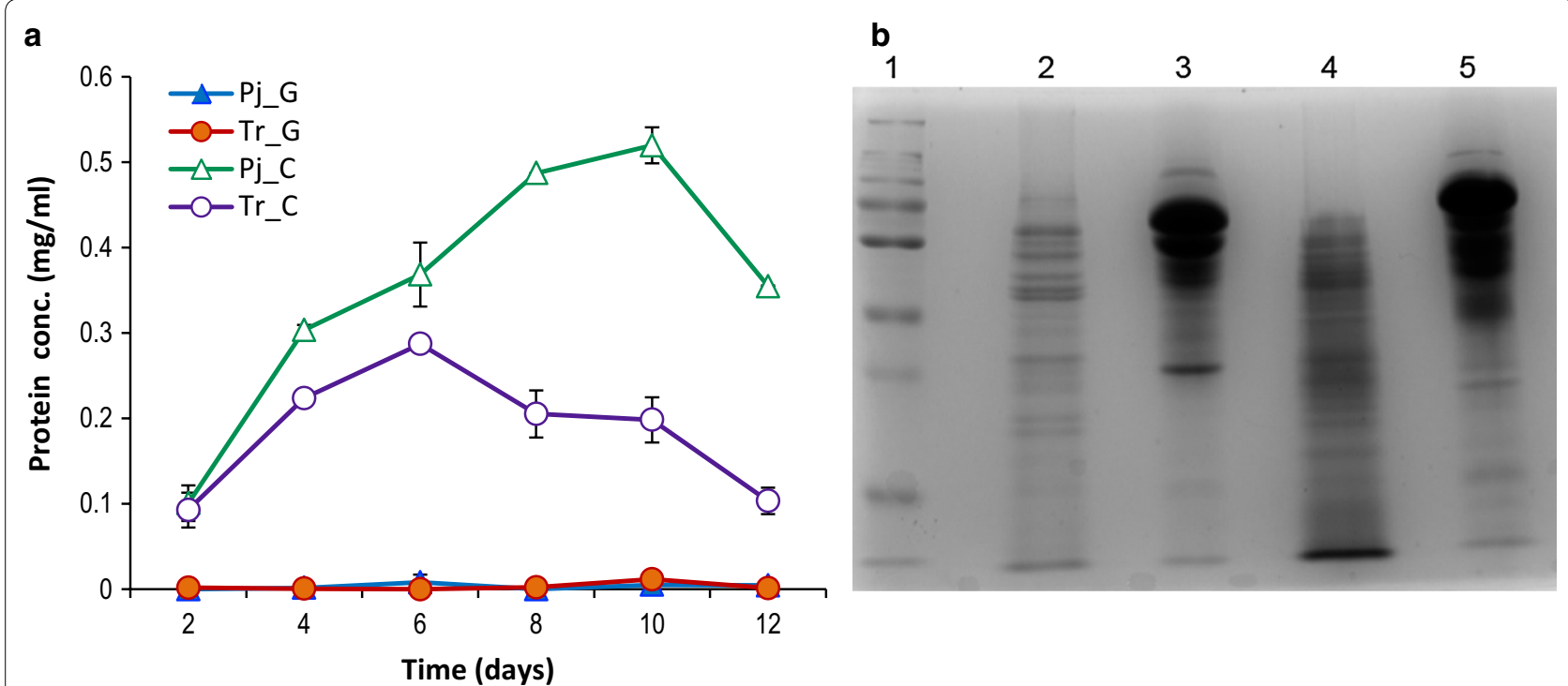

Fig. 1 Extracellular protein production by T. reesei and P.janthinellum in response to induction by cellulose. a Extracellular protein concentrations in T. reesei $(\mathrm{Tr})$ and $P$. janthinellum $(\mathrm{Pj})$ at different time points when cultivated in glucose and in cellulose. $\mathbf{b}$ SDS-PAGE showing differences in protein production by the two fungi. Lane information-1) Page Ruler ${ }^{\circledR}$ pre-stained protein ladder, 2) $\operatorname{Tr}$ grown in glucose 3) $\operatorname{Tr}$. grown in cellulose as sole C source 4) Pj grown in glucose 5) Pj. grown in cellulose as sole $\mathrm{C}$ source

beta-glucosidase. Cellobiose accumulation can lead to product inhibition of upstream enzymes (endoglucanases and cellobiohydrolases) thus slowing down the whole hydrolytic process $[15,16]$. T. reesei is known to have limited cellobiase/beta-glucosidase (BGL) activity, and while it may be advantageous for the organism in tight regulation of cellulose metabolism while growing on natural substrates, it is a disadvantage for the biomass hydrolyzing enzyme cocktails produced using the fungus and often the T. reesei enzyme's lack of BGL activity is compensated by addition of BGL enzyme from other organisms. In this study, it was observed that the cellobiose accumulation in the hydrolysis mixtures was higher for the $T$. reesei enzyme compared to $P$. janthinellum, indicating an incomplete digestion due to the inherent low BGL activity of the former (Fig. 2). For acid-pretreated rice straw, there was little or no cellobiose accumulation observed during the $24 \mathrm{~h}$ of hydrolysis, in the case of $P$. janthinellum enzyme, while about $5 \mathrm{mg} / \mathrm{ml}$ cellobiose was observed consistently from 4th hour onwards in the case of $T$. reesei. In alkali pretreated rice straw hydrolysis, the cellobiose concentration increased from $2.42 \mathrm{mg} /$ $\mathrm{ml}$ in $4 \mathrm{~h}$ to $7.45 \mathrm{mg} / \mathrm{ml}$ in $24 \mathrm{~h}$ for $T$. reesei while the maximum cellobiose accumulation in the case of $P$. janthinellum was only $0.76 \mathrm{mg} / \mathrm{ml}$ at $12 \mathrm{~h}$ after which it again decreased. This indicated the efficient removal of cellobiose, from the reaction medium by $P$. janthinellum enzyme, which could be accounted for by the almost tenfold higher beta-glucosidase activity in the fungus. The results are an indicative of an optimum enzyme cocktail from a single fungus that outperforms the conventional cellulase producer.

\section{Cellulases from $P$. janthinellum perform better than $T$. reesei cellulases in the hydrolysis of pretreated biomass}

Both the dilute acid and dilute alkali pretreated rice straw were hydrolyzed better by $P$. janthinellum cellulases compared to enzymes from $T$. reesei, indicated by a significantly higher glucose release (Fig. $3 \mathrm{a}$ and b). At $24 \mathrm{~h}$, glucose release by $T$. reese $i$ and $P$. janthinellum cellulases from acid-pretreated rice straw were $12.94 \pm 0.8 \mathrm{mg} / \mathrm{ml}$ and $17.69 \pm 0.47 \mathrm{mg} / \mathrm{ml}$, respectively, the latter showing a $37 \%$ higher glucose release. Similar results were observed for alkali-pretreated rice straw, where $P$. janthinellum enzyme released $27.24 \pm 0.22 \mathrm{mg} / \mathrm{ml}$ of glucose which was $43 \%$ higher than the T. reesei cellulase. Also, the glucose release for both the acid and alkali pretreated biomasses was higher with $P$. janthinellum cellulase at all the measured time points. Total sugar release from acid-pretreated rice straw, calculated as the sum of the concentrations of glucose, xylose, arabinose and mannose in the hydrolysis mixture, was $17.88 \pm 0.5 \mathrm{mg} / \mathrm{ml}$ for T. reesei enzyme and $22.41 \pm 0.23 \mathrm{mg} / \mathrm{ml}$ for $P$. janthinellum enzyme. For alkali-pretreated rice straw, the hydrolysate sugar contents were $29.49 \pm 0.57 \mathrm{mg} / \mathrm{ml}$ and $32.94 \pm 0.87 \mathrm{mg} / \mathrm{ml}$, respectively, for $T$. reesei and $P$. janthinellum enzymes (Fig. 3a and b). P. janthinellum enzyme released $25 \%$ higher glucose and $11 \%$ higher total 

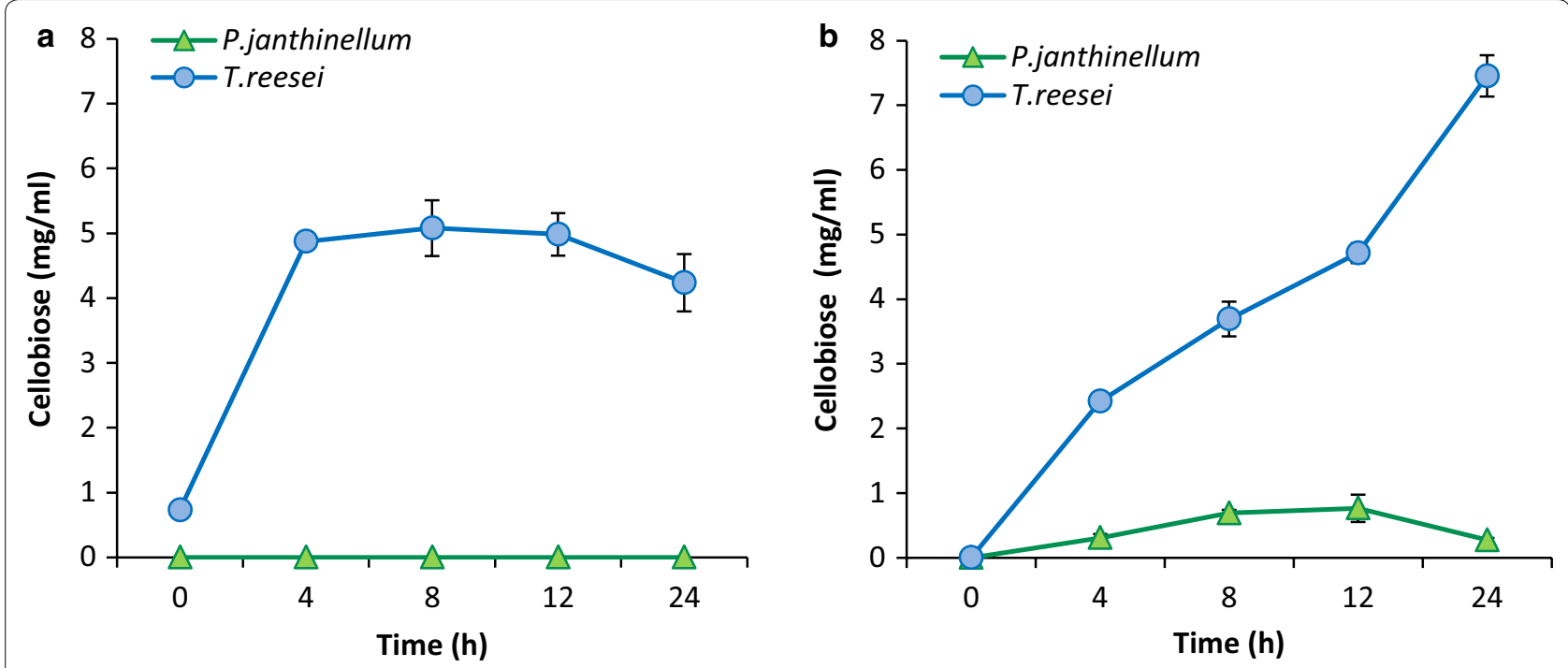

Fig. 2 Cellobiose accumulation during hydrolysis of biomass using T. reesei or P. janthinellum enzymes. a Acid-pretreated rice straw, $\mathbf{b}$ alkali-pretreated rice straw

sugars from alkali pretreated rice straw sugars compared to $T$. reesei enzyme.

The choice of substrate for the hydrolysis reaction often affects the efficiency of glucose release, and enzyme performance could be different on different biomass substrates. Two different biomasses with significantly different properties, viz. sugar cane bagasse and Eucalyptus leaves pretreated using acid or alkali, were used as substrates for testing hydrolytic efficiency of enzymes from both the fungi. Both the biomasses, regardless of the method of pretreatment were hydrolyzed better by $P$. janthinellum enzyme, indicated by higher glucose release. For acid-pretreated sugarcane bagasse, the glucose release at $24 \mathrm{~h}$ was $24.19 \pm 0.34$ for $P$. janthinellum enzyme and $15.54 \pm 0.76$ for $T$. reesei enzyme, while in the case of alkali-pretreated biomass, it was $22.16 \pm 0.35$ and $17.87 \pm 0.91$, respectively, for P. janthinellum and $T$. reesei. Similar results were obtained for eucalyptus leaves, for which the glucose release across treatments were less compared to other biomass types (Fig. $3 \mathrm{c}$ and d).

\section{P. janthinellum produces higher enzyme titers compared to $T$. reesei}

To know how each of the major components of cellulolytic system contribute to the hydrolytic efficiency of $P$. janthinellum cellulase cocktail, standard cellulase assays were performed, on the enzymes produced by the fungi. Extracellular enzyme production in this case was carried out using the same medium and under identical conditions of growth. Secreted enzymes from both fungi were analyzed for the total cellulase, endoglucanase and beta-glucosidase activities. Both T. reesei and P. janthinellum showed maximum cellulase activity on the 10th day, but the FPAse activity of P. janthinellum (0.83 FPU/ $\mathrm{ml})$ was $28 \%$ higher than that of T. reesei $(0.65 \mathrm{FPU} / \mathrm{ml})$ (Fig. 4a). Peak endoglucanase activity of $21.72 \mathrm{IU} / \mathrm{ml}$ was shown by $P$. janthinellum on the 12 th day, whereas T. reesei showed maximum activity $(15.55 \mathrm{IU} / \mathrm{ml})$ at 10th day (Fig. 4b). T. reesei showed an endoglucanase activity of $12.93 \mathrm{IU} / \mathrm{ml}$ even at 6 th day, but the levels were raised only upto $15.55 \mathrm{IU} / \mathrm{ml}$ on 10th day and were not sustained at further time points, probably indicating a feedback inhibition through glucose accumulation. $P$. janthinellum on the contrary, had a lower initial endoglucanase activity $(9.55 \mathrm{IU} / \mathrm{ml})$ which steadily increased to $21.72 \mathrm{IU} / \mathrm{ml}$ on 12th day and showed an ascending trend. The largest difference in enzyme activity between the two fungi was observed in the case of beta-glucosidase (BGL) activity. Highest BGL activity in the case of T. reesei was $10.15 \mathrm{U} / \mathrm{ml}$. P. janthinellum also showed the highest BGL activity $(95.42 \mathrm{U} / \mathrm{ml})$ on the 10 th day (Fig. 4c). Also, the fungus produced $24.88 \mathrm{U} / \mathrm{ml}$ activity on the 2nd day, where T. reesei could elaborate only $1.68 \mathrm{U} / \mathrm{ml}$. These results are remarkable as the betaglucosidase activity at peak levels by the two fungi is different by an almost tenfold margin. Also, it becomes evident that the expression of BGL sets in early in the $P$. janthinellum which would allow it to hydrolyze cellulose faster and prevent cellobiose accumulation, which in turn may help to overcome an early setting in of feedback inhibition. The results were also confirmed by a zymogram analysis which showed a prominent BGL 

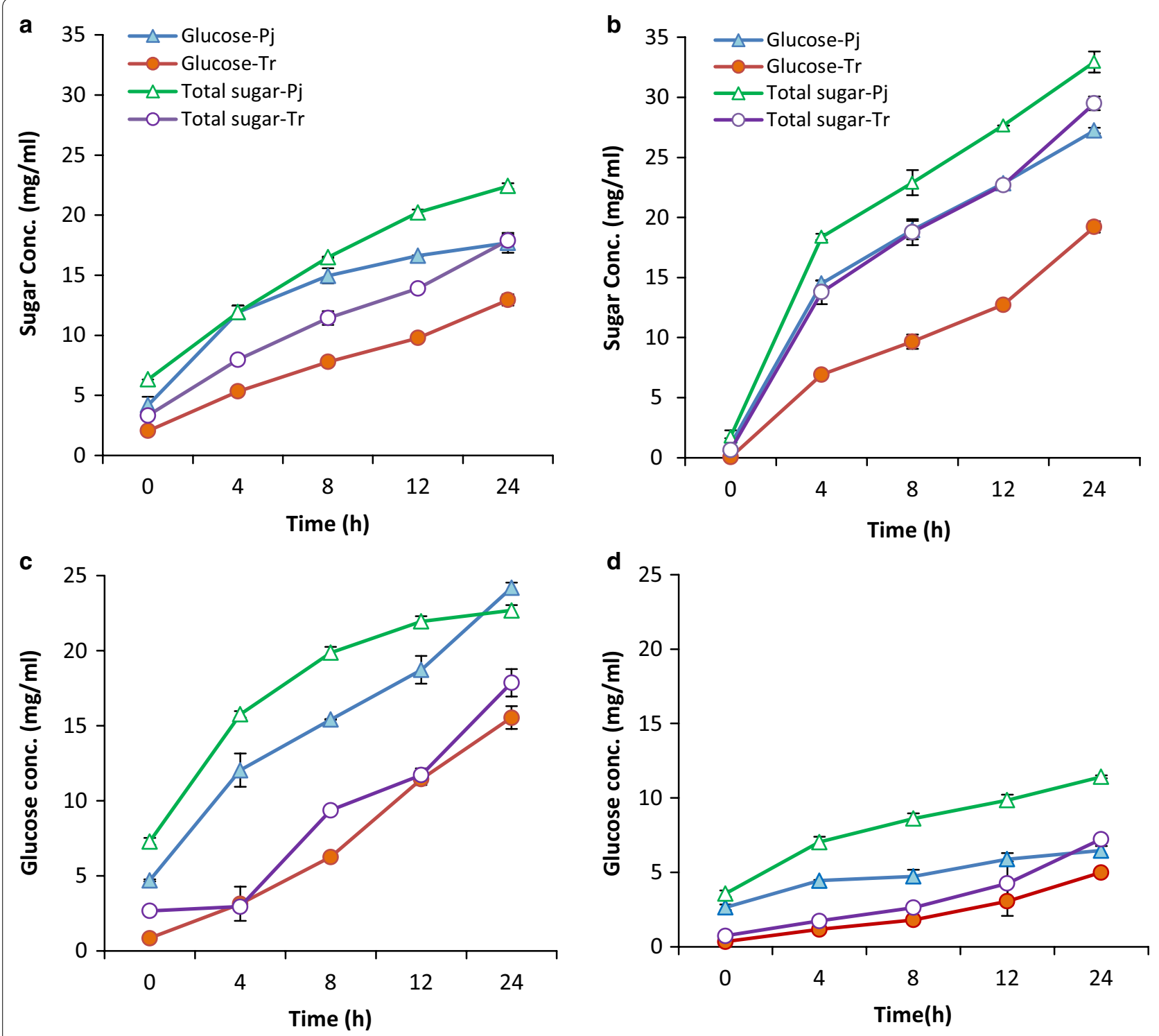

$$
\begin{array}{ll}
- \text { Acid pretreated-Pj } & - \text { Acid pretreted-Tr } \\
-\triangle \text { Alkali pretreated-Pj } & -0 \text {-Alkalipretreted-Tr }
\end{array}
$$

$$
\begin{array}{ll}
- \text { - Acid pretreated-Pj } & -0 \text {-Acid pretreted-Tr } \\
-\triangle \text { - Alkali pretreated-Pj } & -0-\text { Alkalipretreted-Tr }
\end{array}
$$

Fig. 3 Sugar release on enzymatic hydrolysis of pretreated biomass by cellulases from T. reesei RUT C30 and P. janthinellum NCIM 1366. Glucose and total sugar release on enzymatic hydrolysis using T. reesei (Tr) and P. janthinellum (Pj) cellulases from $\mathbf{a}$ acid-pretreated rice straw and $\mathbf{b}$ alkali-pretreated rice straw. Glucose release on hydrolysis using $\operatorname{Tr}$ or Pj cellulases from c sugarcane bagasse, $\mathbf{d}$ eucalyptus leaves

activity band in P. janthinellum, whereas the T. reesei BGL band was barely visible (Fig. 4d).

\section{Comparative secretome analysis of cellulose-induced} cultures confirm secretion of a relatively larger number of CAZymes and lignocellulose active enzymes by $P$. janthinellum

The observed cellulase activity and hydrolysis activity are contributed by the extracellular enzymes in both organisms. As both cultures showed maximum filter paper activity on 10th day of inoculation in cellulose medium, it was speculated that the maximum repertoire of enzymes are secreted at that time point. For comparison glucose was selected as the non-inducing carbon source. The secreted proteins from both cultures, either grown with glucose as carbon source or upon induction with cellulose on the 10th day of growth, were identified and quantitatively analyzed 

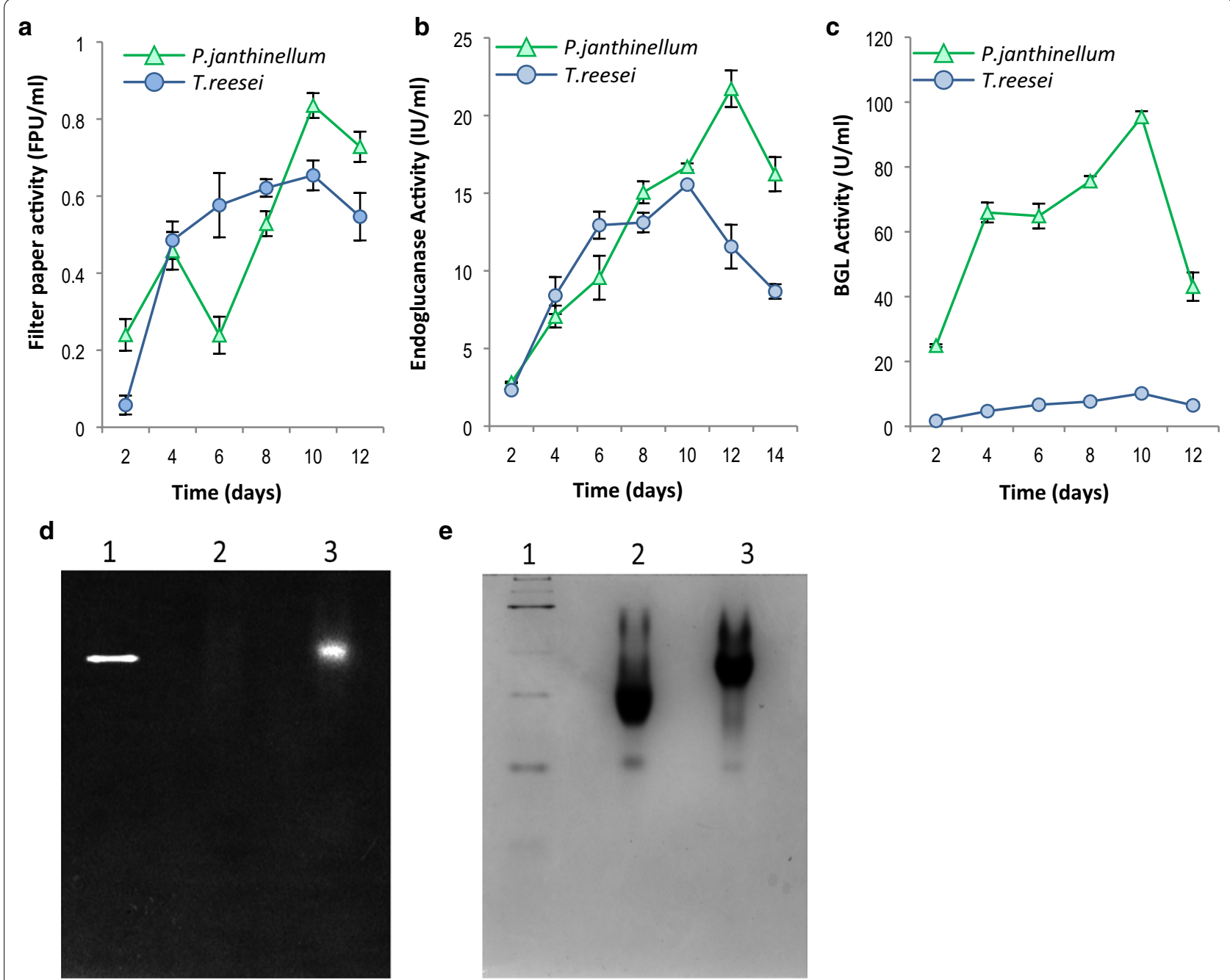

e

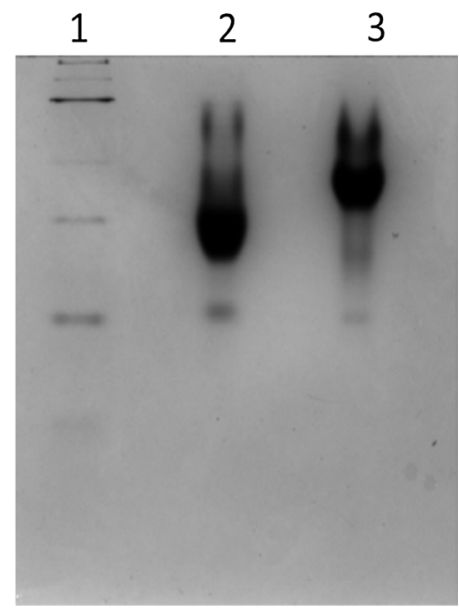

Fig. 4 Extracellular cellulase production by T. reesei and P.janthinellum in Mandels and Weber medium with cellulose as sole carbon source. a Total cellulase activity (filter paper units), b endoglucanase activity (CMCase), $\mathbf{c}$ beta-glucosidase (BGL) activity. $\mathbf{d}$ Zymogram analysis showing BGL activity as MUG fluorescence. e Native PAGE showing protein profile of T. reesei and P. janthinellum secreted enzymes (Lane1-NativeMark ${ }^{\mathrm{TM}}$ unstained protein standard from Invitrogen, Lane2 - T. reesei enzyme extract, Lane3 - P. janthinellum enzyme extract for both $\mathbf{d}$ and $\mathbf{e}$

by liquid chromatography tandem mass spectrometry (LC-MS/MS) analysis. Additional file 1: Table S1, and Additional file 2: Table S2 lists all the proteins, their Uniprot accession number, molecular weights, number of unique peptides, normalized abundance in glucose and cellulose grown cultures and fold change of upon induction for both T. reesei RUT-C30 and $P$. janthinellum NCIM1366 cultures, respectively. Our analysis detected a total of 53 proteins from T. reesei and 85 proteins from P. janthinellum in the 10th day secretome. The distribution of proteins according to their biological function is shown in Fig. 5. Among them, 27 proteins from $T$. reesei (51\%) and 29 proteins from P. janthinellum (34\%) were predicted to have an $\mathrm{N}$ terminal signal peptide using SignalP5.0 server. The identification of proteins without a signal peptide in the secretome could be indicative of the presence of cell lysis, cell death, or secretion through unconventional mechanisms [17]. Figure 6 shows the top 10 highly expressed proteins, as measured by the normalized abundance of their peptides in cellulose-induced cultures, compared to the control (grown in glucose). Most of the highly expressed proteins from both organisms were directly involved in the lignocellulose degradation.

Since it appeared from the forgoing studies that the reason for better overall cellulolytic activity and hydrolytic efficiency of $P$. janthinellum could be its secretion of a larger number of proteins, most of which are known to be involved in lignocellulose hydrolysis, it was 

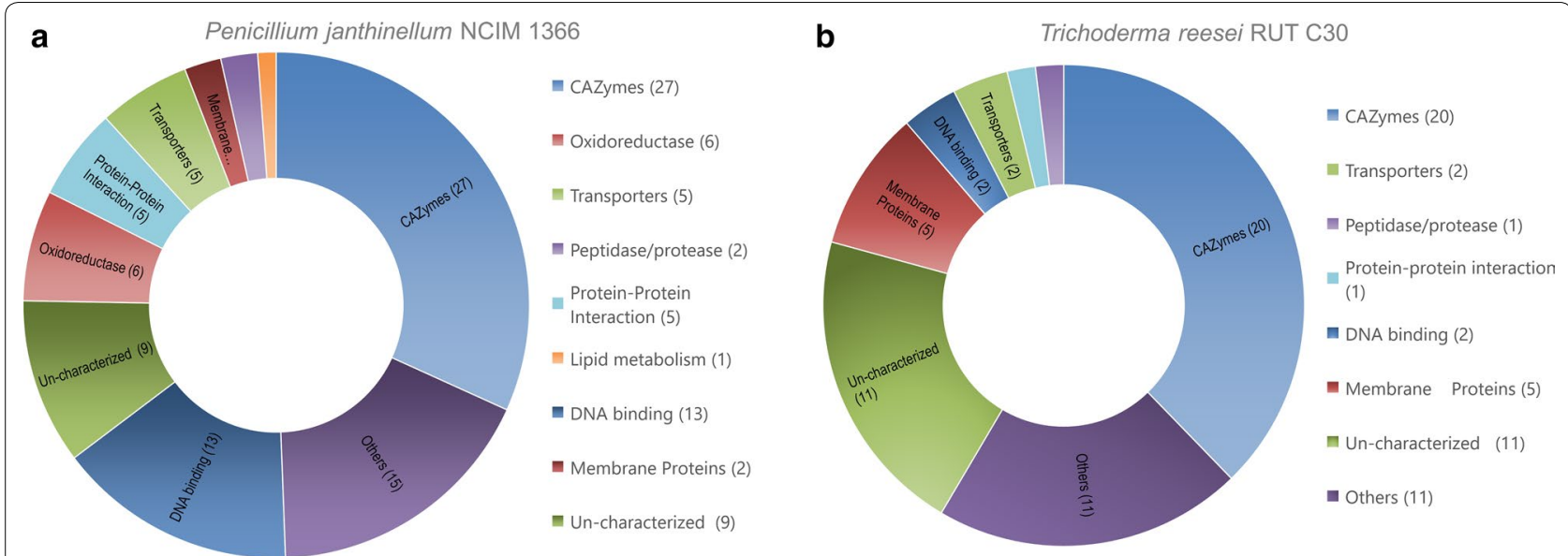

Fig. 5 Functional categories of proteins secreted on cellulose induction by P.janthinellum and T. reesei. a P. janthinellum, $\mathbf{b}$ T. reesei

speculated that the organism could elaborate more cellulolytic enzymes and/or accessory proteins compared to the industrial workhorse- $-T$. reesei. An analysis of the CAZymes in the total secretomes was performed to understand their distribution in the extracellular proteins of both fungi. Among the 53 secreted proteins detected in T. reesei, 20 were identified as CAZymes (Fig. 5a) and the number of CAZymes identified in the 85 identified secreted proteins of $P$. Janthinellum were 27 (Fig. 5b). The distribution of proteins among different CAZy families and the distribution of glycosyl hydrolase $(\mathrm{GH})$ family proteins in both the fungi are shown in Fig. 7. CAZymes from $P$. janthinellum were mostly $\mathrm{GH}$ family proteins except one in GT family. The CAZymes from T. reesei RUT-C30 were distributed to more CAZy families which included GH (glycoside hydrolases), CE (carbohydrate esterases), AA (auxiliary activities) and CBM (carbohydrate-binding module). In the case of GH family proteins, $P$. janthinellum secretome had almost double the number of different Glycoside Hydrolases compared to T. reesei. GH family proteins from $P$. janthinellum spanned over $12 \mathrm{GH}$ subfamilies while for $T$. reesei it was $11 \mathrm{GH}$ subfamilies. GH subfamilies 5, 6, 7 and 11 were detected in both secretomes while GH subfamilies 3, 4, 16, 17, 30 and 72 were detected only in $T$. reesei and GH subfamilies $2,15,27,28,36,43,55$ and 75 , were detected only in $P$. janthinellum.

Table 1 shows the list of CAZymes identified from the secretomes of P. janthinellum and T. reesei. Among the CAZymes detected, a total of 17 enzymes which are directly involved in cellulose hydrolysis were detected, of which 3 were common to both fungi, which were cellobiohydrolase1 (CBH1) (Uniprot accession: P62694,
A0A088DLG0), cellobiohydrolase2 (CBH2) (P07987, F1CHI2) and endoglucanase 1 (EG-1) (A0A024SNB7, A0A0F7TSC9). The two cellobiohydrolases showed higher abundance in P. janthinellum and the endoglucanase showed higher abundance in $T$. reesei. Apart from the EG-1, two other endoglucanases, EG-II (P07982) and EG-V (A0A024S5P6), are identified from T. reesei. In P. janthinellum, 10 cellobiohydrolases and 2 endoglucanases were identified from the common cellulases. However, it may be noted that multiple peptide tags may be matching the same $P$. janthinellum NCIM 1366 gene sequence in reality, which may not be captured on analyzing against the genome (s) of other Penicillium species' genomes as is the case here. While P. janthinellum exhibited 10 times the BGL activity of T. reesei, no beta-glucosidases were identified in both the fungi. Therefore, there was no way to confirm if the higher BGL activity obtained experimentally for $P$. janthinellum correlates to a higher amount of the corresponding protein in the secretome. It was previously observed that the BGL proteins had high specific activities and minute quantities can give high hydrolytic efficiencies, even though their proteins were undetectable by conventional means.

There were 9 enzymes involved in hemicellulose degradation identified from the secretome of T. reesei, while 6 were identified in $P$. janthinellum, of which 2 were common with $T$. reesei. Chitin-degrading enzymes were also identified from both secretomes but pectindegrading enzymes were identified only in P. janthinellum. Accessory activities known to aid cellulose hydrolysis in T. reesei, swollenin (A0A024RZP7) and lytic polysaccharide monooxygenase (A0A024SM10) 


\section{a}

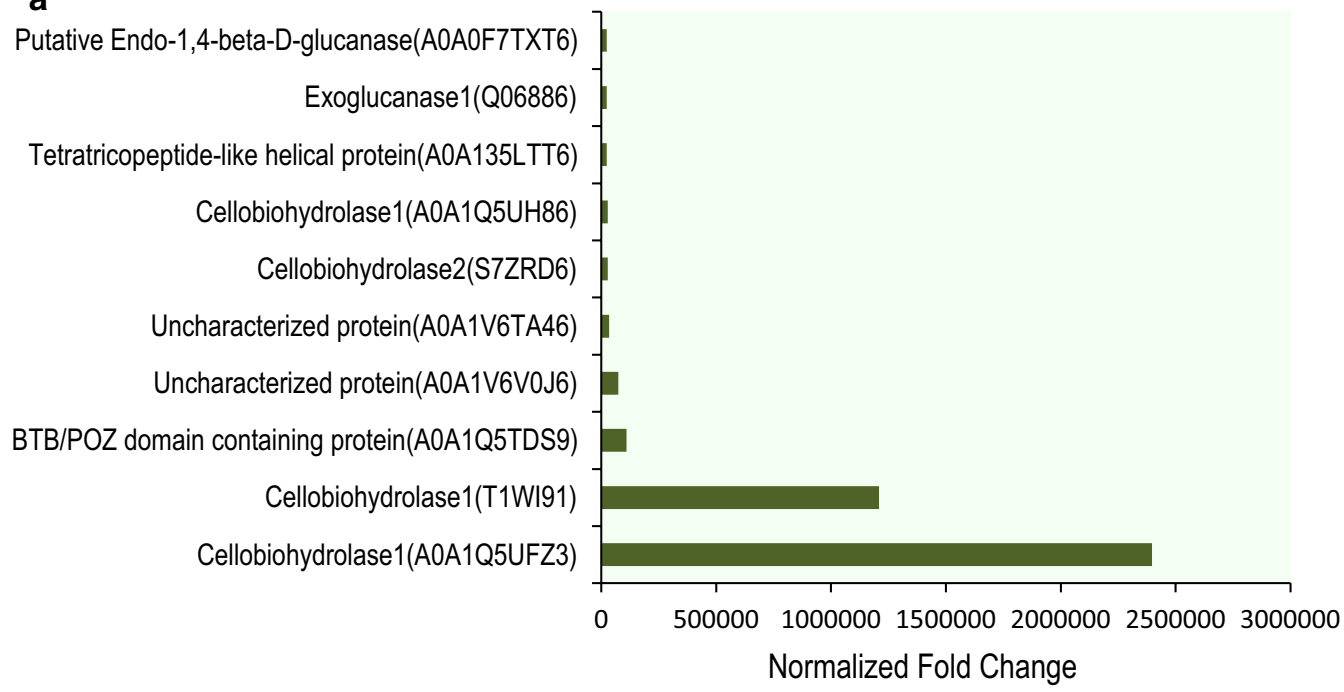

b

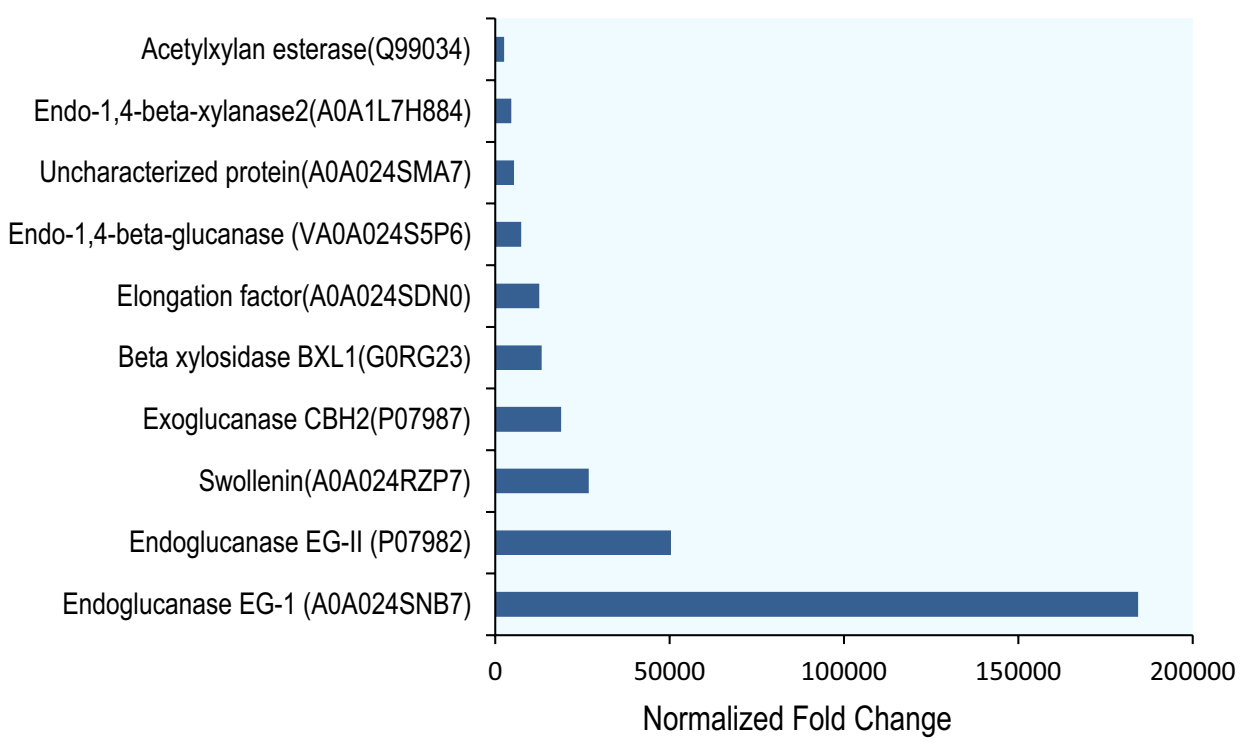

Fig. 6 Most highly expressed proteins in the secretome of P.janthinellum and T. reesei, on cellulose induction. a P. janthinellum, b T. reesei

were identified in the secretome of T. reesei, while these activities were not detected in P. janthinellum. In general, the relative abundance of most of the CAZymes were high in P. janthinellum compared to T. reesei and one of the cellobiohydrolases (A0A1Q5UFZ3) from GH7 family showed a very high relative abundance of 2.3 million. Though P. janthinellum did not show the accessory enzymes/activities in its secretome, it does not necessarily mean that the fungus lacks them, and further confirmations from the genome analysis is awaited.

\section{Discussion}

Lignocellulose-degrading enzymes are critical in biomass conversion to biofuels and filamentous fungi are typically used for the production of these enzymes because of their ability to synthesize and secrete a wide array of plant cell wall-degrading enzymes [18]. T. reesei RUTC30 is the most widely used fungus for cellulase production, despite it having a lower titer of beta-glucosidases and much lesser number of CAZymes compared to certain other fungi. This is primarily due to the fact that $T$. reesei produces the highest known titers of enzymes, the extracellular protein concentrations reaching as high $100 \mathrm{~g} / \mathrm{L}$ [19]; and there is a wealth of information 


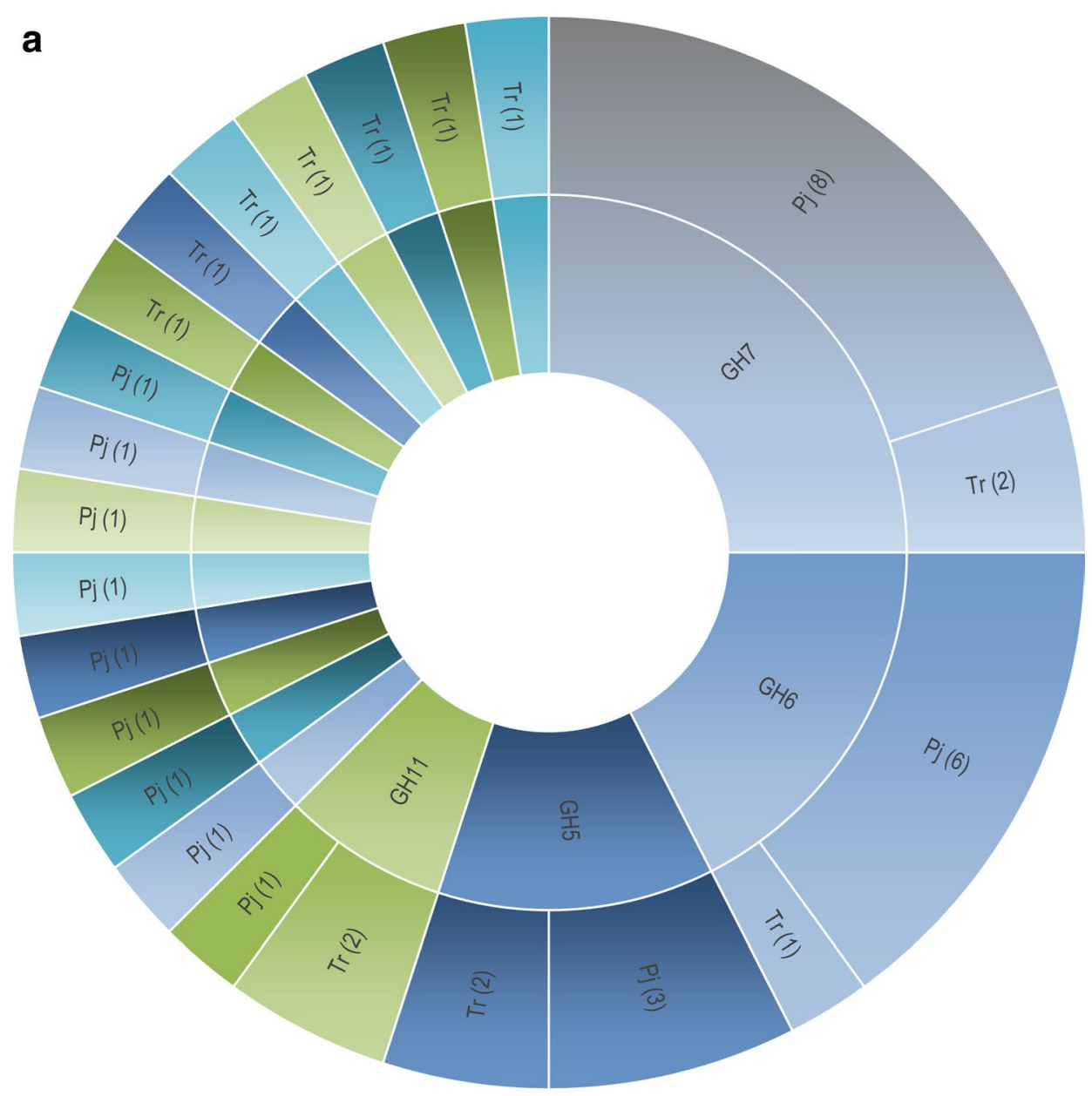

\section{b}

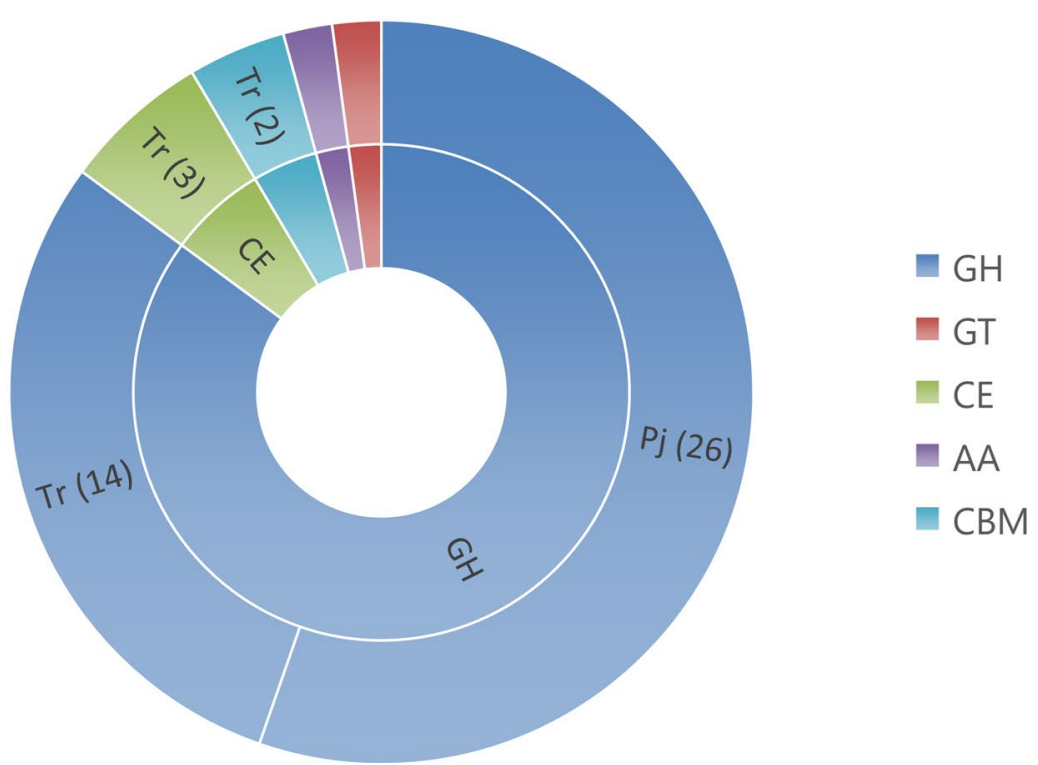

Fig. 7 Distribution of secreted proteins of the fungi in different CAZyme families, and the glycosyl hydrolase family representation in the secretome. a Secreted protein distribution in CAZyme families, $\mathbf{b}$ distribution of glycosyl hydrolases in subfamilies. Tr, T. reesei; Pj, P.janthinellum 
Table 1 CAZymes identified from the secretomes of $P$. janthinellum and $T$. reesei

\begin{tabular}{|c|c|c|c|c|c|c|c|c|c|}
\hline CAZy family & Enzyme & Uniprot accession(s) & Tr-Glu & Tr-Cel & Tr-FC & Pj-Glu & Pj-Cel & Pj-FC & Presence \\
\hline \multicolumn{10}{|c|}{ Cellulose hydrolysis/metabolism } \\
\hline GH5 & Endoglucanase EG-II & P07982 & 1.92 & 96905 & 50333 & - & - & - & $\operatorname{Tr}$ \\
\hline GH5 & Endoglucanase B & A0A1Q5UIH7 & - & - & - & 14.5 & 1256 & 86 & Pj \\
\hline GH5 & Putative endo-1,4-beta-D-glucanase & AOAOF7TXT6 & - & - & - & 0 & 22950 & 22950 & $\mathrm{Pj}$ \\
\hline GH6 & Exoglucanase $6 \mathrm{~A}$ & A0A1Q5UI44 & - & - & - & 0 & 11744 & 11744 & Pj \\
\hline GH6 & Exoglucanase $\mathrm{CBH} 2$ & P07987, F1CHI2 & 13.6 & 256595 & 18844 & 0.24 & 4989 & 20,734 & $\operatorname{Pj} \& \operatorname{Tr}$ \\
\hline GH6 & Cellobiohydrolase & A0A1Q5UIA5 & - & - & - & 0.33 & 6916 & 20958 & Pj \\
\hline GH6 & Cellobiohydrolase & A0A0F7TT91 & - & - & - & - & - & - & Pj \\
\hline $\mathrm{GH} 6$ & Cellobiohydrolase & A0A1F5LUH2 & - & - & - & - & - & - & $\mathrm{Pj}$ \\
\hline $\mathrm{GH7}$ & Exoglucanase $\mathrm{CBH} 1$ & P62694, A0A088DLG0 & 925 & 388093 & 419 & 0.13 & 2607 & 20054 & $\operatorname{Pj} \& \operatorname{Tr}$ \\
\hline $\mathrm{GH7}$ & Glucanase & S7ZRD6 & - & - & - & 0 & 28328 & 28328 & Pj \\
\hline $\mathrm{GH} 7$ & Cellobiohydrolase1 & A0A1Q5UFZ3 & - & - & - & 0.0036 & 8742 & 2396804 & $\mathrm{Pj}$ \\
\hline $\mathrm{GH} 7$ & Cellobiohydrolase 1 & A0A1Q5UH86 & - & - & - & 0.36 & 10266 & 28516 & $\mathrm{Pj}$ \\
\hline $\mathrm{GH} 7$ & Cellobiohydrolase 1 & T1W191 & - & - & - & 0.00058 & 711 & 1225862 & $\mathrm{Pj}$ \\
\hline $\mathrm{GH} 7$ & Exoglucanase1 & Q06886 & - & - & - & 14.6 & 345207 & 23487 & $\mathrm{Pj}$ \\
\hline GH7 & Cellobiohydrolase & A0A0F7TQ87 & - & - & - & - & - & - & Pj \\
\hline $\mathrm{GH7}$ & Endoglucanase EG-1 & A0A024SNB7, A0A0F7TSC9 & 0.42 & 77136 & 183567 & 29.5 & 12605 & 426 & $\operatorname{Pj} \& \operatorname{Tr}$ \\
\hline $\mathrm{GH} 45$ & Endo-1,4-beta-glucanase $V$ & A0A024S5P6 & 3 & 22586 & 7407 & - & - & - & $\operatorname{Tr}]$ \\
\hline \multicolumn{10}{|c|}{ Hemicellulose hydrolysis/metabolism } \\
\hline $\mathrm{GH} 2$ & Beta-mannosidase & $\mathrm{A} 0 \mathrm{~A} 2 \mathrm{H} 3 \mathrm{H} X 4$ & - & - & - & 11.8 & 240 & 20 & $\mathrm{Pj}$ \\
\hline $\mathrm{GH} 3$ & Beta-xylosidase BXL1 & G0RG23 & 2.8 & 37715 & 13278 & - & - & - & $\operatorname{Tr}$ \\
\hline GH5 & Mannan endo-1_4-beta-mannosidase & Q99036, A0A1Q5SW99 & 12.8 & 1387 & 107 & 24.4 & 1891 & 77 & $\operatorname{Pj} \& \operatorname{Tr}$ \\
\hline $\mathrm{GH} 11$ & Endo-1,4-beta-xylanase2 & A0A1L7H884, A0A088S933 & 0 & 4530 & 4530 & 20 & 833 & 40 & $\operatorname{Pj} \& \operatorname{Tr}$ \\
\hline GH11 & Endo-1,4-beta-xylanase1 & $\mathrm{A} 0 \mathrm{~A} 2 \mathrm{H} 3 \mathrm{~A} 3 \mathrm{Q} 5$ & 110 & 32909 & 299 & - & - & - & $\operatorname{Tr}$ \\
\hline GH17 & Beta-1,3-endoglucanase & A0A024SAF4 & 385 & 264 & 1.4 & - & - & - & $\operatorname{Tr}$ \\
\hline $\mathrm{GH} 27$ & Alpha-galactosidase & A0A0F7KIJ2 & - & - & - & 0 & 5173 & 5173 & $\mathrm{Pj}$ \\
\hline $\mathrm{GH} 30$ & Endo-beta-1,4-xylanase4 & A0A024RV01 & 34.5 & 3052 & 88 & - & - & - & $\operatorname{Tr}$ \\
\hline $\mathrm{GH} 43$ & Putative exo-beta-1,3-galactanase & S7ZCW4 & - & - & - & 78.2 & 1900 & 24 & Pj \\
\hline GH55 & Exo-beta-1,3-glucanase & S8BDR6 & - & - & - & 117 & 13.9 & 8.4 & $\mathrm{Pj}$ \\
\hline CE05 & Acetylxylan esterase & Q99034 & 19.5 & 49211 & 2522 & - & - & - & $\operatorname{Tr}$ \\
\hline CE16 & Acetyl esterase & A0A024SFG8 & 10.8 & 24711 & 2273 & - & - & - & $\operatorname{Tr}$ \\
\hline CE16 & Acetyl esterase & A0A2H3A8G3 & 18.6 & 1573 & 84 & - & - & - & $\operatorname{Tr}$ \\
\hline \multicolumn{10}{|c|}{ Chitin hydrolysis/metabolism } \\
\hline GH18 & Chitinase2 & A0A024SOK1 & 11.2 & 597 & 53 & - & - & - & $\operatorname{Tr}$ \\
\hline GH75 & Endo-chitosanase & A0A1Q5UKX2 & - & - & - & 422 & 1340 & 3.1 & $\mathrm{Pj}$ \\
\hline GH84 & $\begin{array}{l}\text { Putative bifunctional alpha- } \\
\text { glucuronidase/N-acetyl beta-glucosa- } \\
\text { minidase }\end{array}$ & S7ZNU5 & - & - & - & 534 & 1572 & 2.9 & Pj \\
\hline \multicolumn{10}{|c|}{ Starch hydrolysis/metabolism } \\
\hline $\mathrm{GH} 15$ & Glucoamylase & A0A093V3D6 & - & - & - & 223 & 0 & 0.0044 & $\mathrm{Pj}$ \\
\hline \multicolumn{10}{|l|}{ Pectin } \\
\hline $\mathrm{GH} 28$ & Endo-polygalacturonase & A0A1Q5UPK8 & - & - & - & 56 & 3631 & 64 & Pj \\
\hline \multicolumn{10}{|c|}{ Accessory activities/other enzymes } \\
\hline AA9 & Polysaccharide monooxygenase CEL61A & A0A024SM10 & 2.85 & 2817 & 987 & - & - & - & $\operatorname{Tr}$ \\
\hline CBM1 & Swollenin & A0A024RZP7 & 0.75 & 20249 & 26748 & - & - & - & $\operatorname{Tr}$ \\
\hline CBM1 & CBM1 domain containing protein & A0A024SJK4 & 104 & 3661 & 35 & - & - & - & $\operatorname{Tr}$ \\
\hline GH16 & Glucanosyl transferase & A0A024S7E6 & 787 & 2014 & 2 & - & - & - & $\operatorname{Tr}$ \\
\hline GH36 & $\begin{array}{l}\text { Putative galactinol sucrose galactosyl } \\
\text { transferase }\end{array}$ & A0A1V6YI05 & - & - & - & 0 & 2804 & 2804 & Pj \\
\hline $\mathrm{GH} 72$ & 1_3-Beta-glucanosyl transferase & A0A024RXP9 & 7.9 & 3225 & 405 & - & - & - & $\operatorname{Tr}$ \\
\hline GT31 & Glycosyl transferase & B8MG06 & - & - & - & 20 & 825 & 40 & $\mathrm{Pj}$ \\
\hline
\end{tabular}


Table 1 (continued)

Tr, Trichoderma reesei RUT C30, Pj, Penicillium janthinellum NCIM 1366,

Tr-Cel, Pj-Cel, T. reesei or P. janthinellum grown with cellulose as carbon source (induced),

Tr-Glu, Pj-Glu, T. reesei or P. janthinellum grown with glucose as carbon source (uninduced)

accumulated on its genetics and gene regulation through works spanning several decades [20]. However, there are still efforts targeted at improving its enzyme production $[21,22]$ as the cost of cellulases cannot yet be considered as economical for biorefinery operations. P. janthinellum NCIM 1366 is a mutant strain developed at the National Chemical Laboratory, Pune, India, through classical mutagenesis and which exhibited enhanced cellulase production compared to the parent strain NCIM 1171 [11]. The extracellular enzyme preparation from the strain was found in this study to be more efficient than the T. reesei enzyme in the hydrolysis of pretreated rice straw. The cellulase system of the fungus is relatively unexplored and the present study aimed to study the cellulases from $P$. janthinellum and compare it with established cellulase hyper producer Trichoderma reesei RUT-C30.

Experiments were designed to assess the efficiencies of both cellulase preparations for the hydrolysis of rice straw, pretreated using the most common methods of dilute acid or dilute alkali treatment at high temperature. The enzyme from $P$. janthinellum hydrolyzed the pretreated rice straw biomass better, indicated by the higher glucose release. Interestingly, the glucose release from acid and alkali pretreated rice straw was, respectively, $37 \%$ and $43 \%$ higher compared to T. reesei. Total sugar release was also higher for $P$. janthinellum enzyme extract. Similar to rice straw, $P$. janthinellum enzyme released higher amount of glucose from sugarcane bagasse and eucalyptus leaves. The results were surprising for a "new" cellulase producer to outperform the established industrial producer. Hence the extracellular enzyme preparations from both fungi were analyzed for their major component activities. These included endoglucanases (EGs), cellobiohydrolases (CBHs), and $\beta$-glucosidases (BGLs), which act in synergism to hydrolyze cellulose [23]. Since the parameters like media composition, $\mathrm{pH}$, carbon source used, etc., can influence the quantity and variety of the cellulase components produced by fungi [24], the basic mineral salts medium of Mandels and Weber [25] with cellulose as the sole carbon source was used for both the organisms to obtain un-biased data. The results showed higher activity for all the three major components with peak activity on 10th day of incubation. Among the enzymes, the largest difference in activity was observed for beta-glucosidase (BGL), which was tenfold higher in P. janthinellum. It is already recognized that the extracellular enzymes of $T$. reesei strains are limited in BGL activity for effective biomass hydrolysis [26]. Thus it may be speculated that the higher BGL activity may be one of the significant factors which can contribute to the higher hydrolytic efficiency shown by $P$. janthinellum cellulase. This was also supported by the fact that the hydrolysis using $T$. reesei cellulase accumulated higher concentration of cellobiose in the medium, indicative of an incomplete hydrolysis. Thus, unlike $T$. reesei enzyme which has to be supplemented with external BGL for hydrolysis reaction [27], P. janthinellum enzyme preparations may be used without the need for any blending or with minimal addition of synergistic BGL preparation (s). In addition to the major cellulases, the total extracellular proteins were also 1.8 times higher for $P$. janthinellum and the qualitative analysis by SDS-PAGE showed more number of proteins in the gel complementing this finding.

Proteomic approaches have been widely used in filamentous fungi for the identification of both intracellular and extracellular proteins [28]. The genome of $T$. reesei QM6a, which is the parent strain of RUT-C30 was first sequenced in 2008 giving insight into its CAZyme system [29]. T. reesei is known to encode at least 10 cellulases, 16 hemicellulases and a total of around 400 CAZymes in its genome. But the composition of secretome varies depending on the carbon source used, culture conditions or experimental parameters. The first proteome analysis of T. reesei RUT-C30 identified a total of 22 proteins using lactose as carbon source [30]. Another study, using different carbon sources identified 230 extracellular proteins and 90 CAZymes [31]. In the present study, using a minimal mineral salt medium under identical conditions, a total of 53 proteins were identified from T. reesei secretome, while $P$. janthinellum secreted 85 different proteins. As expected, most of the proteins identified from both the fungi were related to biomass degradation. More number of CAZymes was identified from P. janthinellum secretome. CAZymes from T. reesei included 2 cellobiohydrolases, 3 endoglucanases, 9 hemicellulases and the accessory activities-swollenin and lytic polysaccharide monooxygenase (LPMO). CAZymes from $P$. janthinellum were grouped into 12 cellobiohydrolases, 3 endoglucanases, and 6 hemicellulases. No beta-glucosidases were identified from both secretomes to support the extremely higher beta-glucosidase activity shown by $P$. janthinellum. However, the number of cellobiohydrolases and their relative abundance was very high in $P$. janthinellum. The proteins identified from the secretome may not be a complete representation of all the CAZymes 
secreted by the organism, as the study used only a single time point and pure cellulose as sole carbon source. The highest differentially expressed protein from $T$. reesei was the GH7 family endoglucanase EG-1, which showed 183,567-fold increase in expression upon cellulose induction. However, $\mathrm{CBH} 1$ is known to be the major secreted protein of T. reesei on cellulose induction [32]. The difference in this study might be a result of the culture conditions and/or the time point of analysis. It could also result from the processing of samples where the insoluble cellulose fraction, which could bind the enzyme, was removed to obtain the supernatant used for analyses. The normalized fold difference shown by the most highly expressed protein from $P$. janthinellum was almost 2 million, and this was a cellobiohydrolase from GH7 family. While $T$. reesei secreted a wider variety of enzymes involved in lignocellulose hydrolysis, it was the $P$. janthinellum that secreted more glycosyl hydrolases and especially very high level of exoglucanases. The study provides preliminary information on the presence of all major cellulolytic and hemicellulolytic activities in the fungus and a very high induction in presence of cellulose, which could account for its enhanced hydrolytic performance.

\section{Conclusions}

Here, we provide the first ever secretome analysis of Penicillium janthinellum NCIM1366 and its comparison with the established cellulase hyper producing industrial strain-Trichoderma reesei RUT-C30. The analyses have highlighted the better hydrolytic efficiency, enzyme activity, protein production and secretion efficiency of $P$. janthinellum, which indicates its potential as future industrial cellulase producer. Further exploration and a deeper understanding on the reasons of its better cellulase production warrants genome and transcriptome level studies on the fungus which is progressing and we aim to reveal soon. Further targeted genetic modifications are expected to improve its performance even more, providing a worthy alternative for $T$. reesei, or complement it in the cellulase applications for biomass conversion.

\section{Methods}

\section{Microorganism and growth medium}

Penicillium janthinellum NCIM1366 was kindly provided by National Culture Collection of Industrial Microorganisms (NCIM), CSIR-National Chemical Laboratory, Pune, India, and Trichoderma reesei RUT-C30 culture was a kind gift from Prof George Szakacs, Technical University of Budapest. The cultures were grown and maintained in potato dextrose agar (PDA) slant. For enzyme production, spores were collected from 20-day-old PDA slants of P. janthinellum NCIM1366 and 5-day-old slants of $T$. reesei RUT-C30.

\section{Enzyme production}

For enzymatic hydrolysis, cellulase enzyme production was carried out under submerged fermentation using optimized media for both organisms. Both media were modified from the original Mandels and Weber medium [25], optimized for growth and cellulase production of the respective organisms. The enzyme production medium for $P$. janthinellum contained (in $\mathrm{g} / \mathrm{L}$ ): $\mathrm{KH}_{2} \mathrm{PO}_{4}(2.0), \mathrm{CaCl}_{2} \cdot 2 \mathrm{H}_{2} \mathrm{O}(0.3)$, urea (0.3), $\mathrm{MgSO}_{4} \cdot 7 \mathrm{H}_{2} \mathrm{O}$ (0.3), ( $\mathrm{NH} 4)_{2} \mathrm{SO}_{4}(1.4)$, peptone (0.75), yeast extract (0.25), Tween- $80(0.5)$ and trace elements: $\mathrm{FeSO}_{4} \cdot 7 \mathrm{H}_{2} \mathrm{O}$ (0.005), $\mathrm{MnSO}_{4} \cdot \mathrm{H}_{2} \mathrm{O}(0.0016), \mathrm{ZnSO}_{4} \cdot 7 \mathrm{H}_{2} \mathrm{O}(0.0014)$, and $\mathrm{CoCl}_{2} \cdot 6 \mathrm{H}_{2} \mathrm{O}(0.002)$ with the $\mathrm{pH}$ of medium adjusted to 5.5. Cellulose $(1 \% \mathrm{w} / \mathrm{v})$ and wheat bran $(2.5 \% \mathrm{w} / \mathrm{v})$ were used as carbon sources and a spore suspension containing $1 \times 10^{5}$ spores $/ \mathrm{ml}$ was used as inoculum at $1 \%(\mathrm{v} / \mathrm{v})$ level. For T. reese $i$, the production medium contained (in $\mathrm{g} / \mathrm{L}): \mathrm{KH}_{2} \mathrm{PO}_{4}(2.0),\left(\mathrm{NH}_{4}\right)_{2} \mathrm{HPO}_{4}(2.1)$, yeast extract (2), $\mathrm{NaCl}(0.5), \mathrm{CaCl}_{2} \cdot 2 \mathrm{H}_{2} \mathrm{O}(0.3)$, urea (0.3), $\mathrm{MgSO}_{4} \cdot 7 \mathrm{H}_{2} \mathrm{O}$ (0.3), Tween $80(0.5)$ and trace elements: $\mathrm{FeSO}_{4} \cdot 7 \mathrm{H}_{2} \mathrm{O}$ (0.005), $\mathrm{MnSO}_{4} \cdot \mathrm{H}_{2} \mathrm{O}(0.0016), \mathrm{ZnSO}_{4} \cdot 7 \mathrm{H}_{2} \mathrm{O}(0.0014)$ and $\mathrm{CoCl}_{2} \cdot 6 \mathrm{H}_{2} \mathrm{O}(0.002)$ with $\mathrm{pH}$ of the medium adjusted to 7.2. The carbon sources used were $0.1 \%$ lactose, $2 \%$ cellulose and $1.5 \%$ wheat bran and the medium was inoculated at $1 \%(\mathrm{v} / \mathrm{v})$ level with a $1 \times 10^{6}$ spores $/ \mathrm{ml}$ spore suspension. Cultivation was carried out at $30 \pm 2{ }^{\circ} \mathrm{C}$ and $200 \mathrm{rpm}$ agitation. The extracellular crude enzyme from both cultures was collected after 10 days of incubation, and was assayed for total cellulase activity. Enzyme activity was expressed in filter paper units (FPU).

\section{Comparison of total cellulase activity, endoglucanase activity, and beta-glucosidase activity}

Both organisms were cultivated in the basic Mandels and Weber medium [25] (composition in g/L: $\mathrm{KH}_{2} \mathrm{PO}_{4}$ (2.0), $\mathrm{CaCl}_{2} \cdot 2 \mathrm{H}_{2} \mathrm{O}(0.3)$, urea (0.3), $\mathrm{MgSO}_{4} \cdot 7 \mathrm{H}_{2} \mathrm{O}(0.3)$, $(\mathrm{NH} 4)_{2} \mathrm{SO}_{4}$ (1.4), peptone (0.75), yeast extract $(0.25)$, Tween-80 (0.5) and trace elements $(\mathrm{g} / \mathrm{L}): \mathrm{FeSO}_{4} \cdot 7 \mathrm{H}_{2} \mathrm{O}$ (0.005), $\mathrm{MnSO}_{4} \cdot \mathrm{H}_{2} \mathrm{O}$ (0.0016), $\mathrm{ZnSO}_{4} \cdot 7 \mathrm{H}_{2} \mathrm{O}$ (0.0014), and $\mathrm{CoCl}_{2} \cdot 6 \mathrm{H}_{2} \mathrm{O}(0.002)$ with $\mathrm{pH}$ of the medium adjusted to 5.0 . Cellulose $(1 \% \mathrm{w} / \mathrm{v})$ was used as the sole carbon source. The inoculum size used was $1 \% \mathrm{v} / \mathrm{v}$ of a $1 \times 10^{5}$ spores $/ \mathrm{ml}$ suspension for both the cultures. Cultivation was carried out at $30 \pm 2{ }^{\circ} \mathrm{C}$ and $200 \mathrm{rpm}$ agitation. Samples were collected from the 2nd day onwards, every $48 \mathrm{~h}$. Total cellulase activity (filter paper activity) and endoglucanase (CMCase) activity was determined by the IUPAC method [33] and beta-glucosidase activity was determined as described by Rajasree et al. [34]. One unit of beta-glucosidase activity is defined as the amount 
of enzyme required to liberate $1 \mu \mathrm{g} p$-nitro phenol from pNPG (4-nitrophenyl $\beta$-D-glucopyranoside) per milliliter.

\section{Zymogram analysis of extracellular proteins}

Native poly-acrylamide gel electrophoresis (PAGE) of the extracellular enzyme and methyl umbelliferyl $\beta$-Dglucopyranoside (MUG) staining was performed as described by Rajasree et al. [34].

\section{Comparison of hydrolytic efficiencies and cellobiose accumulation}

Different lignocellulosic biomass, pretreated similarly using either dilute acid or alkali, was used for the hydrolysis studies. For acid pretreatment, biomass $(20 \% \mathrm{w} / \mathrm{v})$ was mixed with $10 \% \mathrm{w} / \mathrm{w}$ of $\mathrm{H}_{2} \mathrm{SO}_{4}$ and was pretreated for $1 \mathrm{~h}$ at $120 \pm 2{ }^{\circ} \mathrm{C}$. The biomass was cooled to room temperature and a slurry was made by adding $2 \times$ volume of water. The $\mathrm{pH}$ of the slurry was adjusted to 6.0 by adding $10 \mathrm{~N} \mathrm{NaOH}$. Solid-liquid separation was performed using a nylon sieve and the biomass was washed twice with tap water. The biomass was used directly after correction of moisture or air dried at room temperature and stored until used. For alkali pretreatment, 20\% w/v rice straw and $10 \% \mathrm{w} / \mathrm{w} \mathrm{NaOH}$ was mixed and pretreated at $120 \pm 2{ }^{\circ} \mathrm{C}$ for $1 \mathrm{~h}$. Water $(2 \times$ volume $)$ was added and the $\mathrm{pH}$ of the pretreated slurry was adjusted to 6 by adding $10 \mathrm{~N} \mathrm{H}_{2} \mathrm{SO}_{4}$. The biomass was then processed as described above.

The hydrolysis reactions ( $20 \mathrm{ml}$ reaction volume) were carried out in screw-capped glass conical flasks with the following conditions: $10 \% \mathrm{w} / \mathrm{w}$ of dry biomass, $10 \mathrm{FPUs} / \mathrm{g}$ enzyme loading and $0.05 \% \mathrm{w} / \mathrm{w}$ surfactant (Tween 80 ) loading. $0.5 \% \mathrm{v} / \mathrm{v}$ of a commercial penicillin/streptomycin mixture (Himedia, India) was added to prevent any bacterial contamination. The hydrolysis reaction was carried out at $50{ }^{\circ} \mathrm{C}$ for $24 \mathrm{~h}$ and samples were collected at $0,4,8,12$ and $24 \mathrm{~h}$ of hydrolysis. The amount of glucose, xylose, arabinose, mannose and cellobiose in the samples was determined using the HPLC as described previously [35].

\section{Comparison of extracellular protein production and secretome analysis}

Both organisms were grown in basic Mandels and Weber medium [25] with either glucose or cellulose at $1 \%(\mathrm{w} / \mathrm{v})$ level as sole carbon sources, as described above. Samples were collected at 48-h intervals starting from the 2nd day. Total secreted proteins present in the samples were estimated by the Bradford method [36] with BSA as standard. SDS-PAGE was carried out as described by Laemmli [37], using 12\% acrylamide gels. Proteins were visualized by staining with Coomassie Brilliant Blue R-250.
For secretome analyses, extracellular proteins were collected by centrifugation for $10 \mathrm{~min}$ at $4{ }^{\circ} \mathrm{C}$ and $13,400 \times \mathrm{g}$ after 10 days of incubation. The supernatants were further clarified by filtration through $1 \mu$ Glass microfiber filter. The collected proteins were dialyzed against $50 \mathrm{mM}$ ammonium bicarbonate buffer and concentrations were normalized. Samples were digested using trypsin following the standard protocol [38]. The proteomic profiling was performed in duplicates by liquid chromatography tandem mass spectrometry (LC-MS/MS) at the Mass Spectrometry \& Proteomics Core facility of Rajiv Gandhi Centre for Biotechnology, Trivandrum, India. The protein samples were subjected to in-solution trypsin digestion using sequence grade trypsin (Sigma Aldrich, India). The LC/MS/MS analyses of the tryptic peptides were performed in a SYNAPT G2 high definition mass spectrometer (Waters, UK), connected to a NanoACQUITY UPLC $^{\circledR}$ chromatographic system (Waters, UK) for the separation of the peptides. The LC-MS/MS acquired raw data were analyzed by Progenesis QI for Proteomics V3.0 (NonLinear Dynamics, Waters, UK) for protein identification using the protein database of Trichoderma reese $i$ and Penicillium downloaded from UniProt repository. Prediction of the presence of secretion signal motifs was achieved using SignalP 5.0 [39].

\section{Identification of CAZymes from secretome data}

Annotation of CAZy (carbohydrate active enzymes) family of proteins as per CAZy database [40] was done through dbCAN2 meta server [41].

\section{Supplementary information}

Supplementary information accompanies this paper at https://doi. org/10.1186/s13068-020-01830-9.

Additional file 1. Proteins identified from the induced and uninduced secretome of $T$. reesei RUTC30.

Additional file 2. Proteins identified from the induced and uninduced secretome of P.janthinellum NCIM 1366.

\begin{abstract}
Acknowledgements
ASR, MC, PKV and MS are thankful to the Council of Scientific and Industrial Research (CSIR), Govt. of India, for the Junior/Senior research fellowships for Ph.D. This study was partially funded by Department of Biotechnology Govt. of India (BT/PR20695/BBE/117/211/2016) and CSIR (MLP 0035: 33/2018/ MD-FTT\&FTC-ANB). We thank Prof. George Szakacs, Technical University of Budapest for the Trichoderma reesei RUT-C30 strain.
\end{abstract}

\section{Authors' contributions}

ASR_-performed most of the experimental work and protein studies. MC, PKV and AA did data analyses and categorization. RKP initiated the original studies on cellulase production from Pj and Tr and established protocols. DVG originally isolated the Pj culture, did classical mutations and also corrected manuscript. MS and AA did biomass pretreatment and hydrolysis of biomass. AP was involved in experiment planning and manuscript corrections. RKS conceptualized the work, planned experiments and work distribution, did 
data interpretation and graphing, drafted manuscript and performed corrections and coordinated the entire work. All authors read and approved the final manuscript.

\section{Funding}

Primary funding of the work is from the contingencies of ASR, MC, PKV and part of the funding from grants for projects BT/PR20695/BBE/117/211/2016 (DBT, Govt. of India) and MLP 0035: 33/2018/MD-FTT\&FTC-ANB (CSIR, Govt. of India).

\section{Availability of data and materials}

All essential data generated or analyzed during this study are included in this published article and its supplementary information files. More elaborate datasets generated during and/or analyzed during the current study available from the corresponding author on reasonable request.

\section{Ethics approval and consent to participate}

This article does not contain any studies with human participants or animals performed by any of the authors.

\section{Consent for publication}

RKS, the corresponding author, declares on behalf of all authors that they do not have data pertaining to individuals.

\section{Competing interests}

The authors declare that they have no competing interests.

\section{Author details}

${ }^{1}$ Biofuels and Biorefineries Section, Microbial Processes and Technology Division, CSIR-National Institute for Interdisciplinary Science and Technology, Industrial Estate, Pappanamcode, Thiruvananthapuram 695019, India. ${ }^{2}$ Academy of Scientific and Innovative Research (AcSIR), Ghaziabad 201002, India. ${ }^{3}$ Department of Microbiology and Cell Biology, Indian Institute of Science, Bangalore 560012, India. ${ }^{4}$ National Chemical Laboratory, Pune, India. ${ }^{5}$ Department of Chemical Engineering, Hanyang University, Seoul, Republic of Korea. ${ }^{6}$ Centre for Innovation and Translational Research, CSIR-Indian Institute of Toxicology Research, Lucknow, India.

Received: 5 August 2020 Accepted: 16 November 2020 Published online: 01 December 2020

\section{References}

1. Chen H. Chemical Composition and Structure of Natural Lignocellulose. In: Biotechnology of Lignocellulose. Dordrecht: Springer Netherlands. 2014; pp. 25-71. https://doi.org/10.1007/978-94-007-6898-7_2

2. Van Dyk JS, Pletschke BI. A review of lignocellulose bioconversion using enzymatic hydrolysis and synergistic cooperation between enzymesFactors affecting enzymes, conversion and synergy. Biotechnol Adv. 2012;30(6):1458-80. https://doi.org/10.1016/j.biotechadv.2012.03.002.

3. Johnson E. Integrated enzyme production lowers the cost of cellulosic ethanol. Biofuels, Bioprod Biorefining. 2016;10(2):164-74. https://doi. org/10.1002/bbb.16344.

4. Glass NL, Schmoll M, Cate JHD, Coradetti S. Plant Cell Wall Deconstruction by Ascomycete Fungi. Annu Rev Microbiol. 2013;67:477-98. https://doi. org/10.1146/annurev-micro-092611-150044.

5. Zhang X-Z, Zhang Y-HP. Cellulases: Characteristics, Sources, Production, and Applications. In: Yang ST, El-Enhasy H, Thongchul N (eds) Bioprocessing Technologies in Biorefinery for Sustainable Production of Fuels, Chemicals, and Polymers, Wiley, Inc., Hoboken: 2013; pp 131-46. https:// doi.org/10.1002/9781118642047.ch8

6. Montenecourt BS, Eveleigh DE. Selective Screening Methods for the Isolation of High Yielding Cellulase Mutants of Trichoderma reesei. In: Brown RD, Jurasek L (eds) Hydrolysis of Cellulose: Mechanisms of Enzymatic and Acid Catalysis, Advances in Chemistry Vol 181, Chapter 14. 1979; pp 289-301. https://doi.org/10.1021/ba-1979-0181.ch014

7. Foreman PK, Brown D, Dankmeyer L, Dean R, Diener S, Dunn-Coleman NS, et al. Transcriptional regulation of biomass-degrading enzymes in the filamentous fungus Trichoderma reesei. J Biol Chem. 2003;278(34):3198897. https://doi.org/10.1074/jbc.m304750200.
8. Ellilä S, Fonseca L, Uchima C, Cota J, Goldman GH, Saloheimo M, et al. Development of a low-cost cellulase production process using Trichoderma reesei for Brazilian biorefineries. Biotechnol Biofuels. 2017;10:30. https://doi.org/10.1186/s13068-017-0717-0.

9. Adsul MG, Ghule JE, Singh R, Shaikh H, Bastawde KB, Gokhale DV, et al. Polysaccharides from bagasse: applications in cellulase and xylanase production. Carbohydr Polym. 2004;57:67-72. https://doi.org/10.1016/j. carbpol.2004.04.001.

10. Adsul MG, Ghule JE, Shaikh H, Singh R, Bastawde KB, Gokhale DV, et al. Enzymatic hydrolysis of delignified bagasse polysaccharides. Carbohydr Polym. 2005;62:6-10. https://doi.org/10.1016/j.carbpol.2005.07.010.

11. Adsul MG, Bastawde KB, Varma AJ, Gokhale DV. Strain improvement of Penicillium janthinellum NCIM 1171 for increased cellulase production. Bioresour Technol. 2007;98(7):1467-73. https://doi.org/10.1016/j.biort ech.2006.02.03612.

12. Adsul MG, Terwadkar AP, Varma AJ, Gokhale DV. Cellulases from penicillium janthinellum mutants: solid-state production and their stability in ionic liquids. BioResources. 2009;4:1670-81. https://doi.org/10.15376/ biores.4.4.1670-1681

13. Singhvi MS, Adsul MG, Gokhale DV. Comparative production of cellulases by mutants of Penicillium janthinellum NCIM 1171 and its application in hydrolysis of Avicel and cellulose. Bioresour Technol. 2011;102:6569-72. https://doi.org/10.1016/j.biortech.2011.01.014.

14. Singhania RR, Saini JK, Saini R, Adsul M, Mathur A, Gupta R, et al. Bioethanol production from wheat straw via enzymatic route employing penicillium janthinellum cellulases. Bioresour Technol. 2014;169:490-5. https:// doi.org/10.1016/j.biortech.2014.07.011.

15. Payne CM, Knott BC, Mayes HB, Hansson H, Himmel ME, Sandgren M, et al. Fungal cellulases. Chem Rev. 2015;115(3):1308-48. https://doi. org/10.1021/cr500351c.

16. Atreya ME, Strobel KL, Clark DS. Alleviating product inhibition in cellulase enzyme Cel7A. Biotechnol Bioeng. 2016;113(2):330-8. https://doi. org/10.1002/bit.25809.

17. Miura N, Ueda M. Evaluation of unconventional protein secretion by Saccharomyces cerevisiae and other fungi. Cells. 2018;7(9):128. https://doi. org/10.3390/cells7090128.

18. Su X, Schmitz G, Zhang M, Mackie RI, Cann IKO. Heterologous gene expression in filamentous fungi. In: Gadd GM, Sariaslani E (eds) Advances in applied microbiology, Volume 81, Elsevier, San Diego, USA; 2012, pp 1-61. https://doi.org/10.1016/B978-0-12-394382-8.00001-0

19. Cherry JR, Fidantsef AL. Directed evolution of industrial enzymes: an update. Curr Opin Biotechnol. 2003;14:438-43. https://doi.org/10.1016/ s0958-1669(03)00099-5.

20. Bischof RH, Ramoni J, Seiboth B. Cellulases and beyond: the first 70 years of the enzyme producer Trichoderma reesei. Microb Cell Fact. 2016;15:113. https://doi.org/10.1186/s12934-016-0507-6.

21. Derntl C, MacH RL, MacH-Aigner AR. Fusion transcription factors for strong, constitutive expression of cellulases and xylanases in Trichoderma reesei. Biotechnol Biofuels. 2019;12:231. https://doi.org/10.1186/s1306 8-019-1575-8.

22. Chen Y, Wu C, Fan X, Zhao X, Zhao X, Shen T, et al. Engineering of Trichoderma reesei for enhanced degradation of lignocellulosic biomass by truncation of the cellulase activator ACE3. Biotechnol Biofuels. 2020;13:62. https://doi.org/10.1186/s13068-020-01701-3.

23. Zhang YHP, Lynd LR. Toward an aggregated understanding of enzymatic hydrolysis of cellulose: noncomplexed cellulase systems. Biotechnol Bioeng. 2004;88(7):97-824. https://doi.org/10.1002/bit.20282.

24. Sukumaran RK, Singhania RR, Pandey A. Microbial cellulases-Production, applications and challenges. J Sci Ind Res. 2005; 832-844. http://nopr. niscair.res.in/handle/123456789/5375

25. Mandels M, Weber J. The production of cellulases, Chap 23. In: Hajny GJ, Reese ET, editors. Cellulases and their applications. advances in chemistry, vol 95. American Chemical Society; 1969. pp 391-414. https://doi. org/10.1021/ba-1969-0095.ch023

26. Saloheimo M, Kuja-Panula J, Ylösmäki E, Ward M, Penttilä M. Enzymatic properties and intracellular localization of the novel Trichoderma reesei $\beta$-glucosidase BGLII (Cel1A). Appl Environ Microbiol. 2002;68(9):4546-53. https://doi.org/10.1128/aem.68.9.4546-4553.2002.

27. Berlin A, Maximenko V, Gilkes N, Saddler J. Optimization of enzyme complexes for lignocellulose hydrolysis. Biotechnol Bioeng. 2007;97(2):287-96. https://doi.org/10.1002/bit.21238. 
28. Fernández RG, Novo JVJ. Proteomic protocols for the study of filamentous fungi. In: Gupta V, Tuohy M, Ayyachamy M, Turner K O'Donovan A, editors. Laboratory protocols in fungal biology. fungal biology. Springer, New York, NY; 2013. pp. 299-308. https://doi. org/10.1007/978-1-4614-2356-0_24

29. Martinez D, Berka RM, Henrissat B, Saloheimo M, Arvas M, Baker SE, et al. Genome sequencing and analysis of the biomass-degrading fungus Trichoderma reesei (syn. Hypocrea jecorina). Nat Biotechnol. 2008;26:55360. https://doi.org/10.1038/nbt1403.

30. Herpoël-Gimbert I, Margeot A, Dolla A, Jan G, Mollé D, Lignon S, et al. Comparative secretome analyses of two Trichoderma reesei RUT-C30 and CL847 hypersecretory strains. Biotechnol Biofuels. 2008;1:18. https://doi. org/10.1186/1754-6834-1-18.

31. Adav SS, Chao LT, Sze SK. Quantitative secretomic analysis of Trichoderma reesei strains reveals enzymatic composition for lignocellulosic biomass degradation. Mol Cell Proteomics. 2012;11(7):M111.012419. https://doi. org/10.1074/mcp.M111.012419.

32. Peterson $\mathrm{R}$, Nevalainen $\mathrm{H}$. Trichoderma reesei RUT-C30 - Thirty years of strain improvement. Microbiology. 2012;158(Pt 1):58-68. https://doi. org/10.1099/mic.0.054031-0.

33. Ghose TK. Measurement of cellulase activities. Pure Appl Chem. 1987;59(2):257-68. https://doi.org/10.1351/pac198759020257.

34. Rajasree KP, Mathew GM, Pandey A, Sukumaran RK. Highly glucose tolerant $\beta$-glucosidase from Aspergillus unguis: NII 08123 for enhanced hydrolysis of biomass. J Ind Microbiol Biotechnol. 2013;40:967-75. https:// doi.org/10.1007/s10295-013-1291-5.

35. Christopher M, Mathew AK, Kiran Kumar M, Pandey A, Sukumaran RK. A biorefinery-based approach for the production of ethanol from enzymatically hydrolysed cotton stalks. Bioresour Technol. 2017;242:17883. https://doi.org/10.1016/j.biortech.2017.03.190.

36. Bradford MM. A rapid and sensitive method for the quantitation of microgram quantities of protein utilizing the principle of protein-dye binding. Anal Biochem. 1976;72(1-2):248-54. https://doi.org/10.1016/00032697(76)90527-3.

37. Laemmli UK. Cleavage of structural proteins during the assembly of the head of bacteriophage T4. Nature. 1970;227:680-5. https://doi. org/10.1038/227680a0.

38. Trauger SA, Webb W, Siuzdak G. Peptide and protein analysis with mass spectrometry. J Spectroscopy. 2002;16:15-28. https://doi. org/10.1155/2002/320152.

39. Armenteros AJJ, Tsirigos KD, Sønderby CK, Petersen TN, Winther O, Brunak $S$, et al. SignalP 50 improves signal peptide predictions using deep neural networks. Nat Biotechnol. 2019;37:420-3. https://doi.org/10.1038/s4158 7-019-0036-Z.

40. Lombard V, Golaconda Ramulu H, Drula E, Coutinho PM, Henrissat B. The carbohydrate-active enzymes database (CAZy) in 2013. Nucleic Acids Res. 2014;42:D490-5. https://doi.org/10.1093/nar/gkt1178.

41. Yin Y, Mao X, Yang J, Chen X, Mao F, Xu Y. DbCAN: a web resource for automated carbohydrate-active enzyme annotation. Nucleic Acids Res. 2012;40:W445-51. https://doi.org/10.1093/nar/gks479.

\section{Publisher's Note}

Springer Nature remains neutral with regard to jurisdictional claims in published maps and institutional affiliations.
Ready to submit your research? Choose BMC and benefit from:

- fast, convenient online submission

- thorough peer review by experienced researchers in your field

- rapid publication on acceptance

- support for research data, including large and complex data types

- gold Open Access which fosters wider collaboration and increased citations

- maximum visibility for your research: over 100M website views per year

At $\mathrm{BMC}$, research is always in progress.

Learn more biomedcentral.com/submissions 